Research Article

\title{
A Critical Review of the Adopted Academic Advising Approaches at the Durban University of Technology: Unpacking its Strengths and Challenges
}

Timothy Aduojo Obaje $\mathrm{i}^{\mathrm{i}}$ \& Rosheena Jeawon ${ }^{\mathrm{ii}}$

\begin{abstract}
This paper offers a critical review of the adopted academic advising strategies at the Durban University of Technology. It is worth acknowledging that academic advising as a scholarly practice is in its developmental stage at South African tertiary institutions. The paper draws on the experiences of the authors as academic advisors to reflect on the strengths and challenges of the practice of academic advising. It interrogates and analyses the authors' experiences vis-à-vis the extant literature on academic advising practices. In this way, the paper engages and advances best practices while simultaneously contributing to the body of literature on academic advising in South Africa.
\end{abstract}

\section{Keywords}

Academic advising, higher education, first-year students, student support, academic excellence

\section{Introduction}

South African higher education institutions (HEIs) are committed to finding ways of creating and developing a productive relationship with all students. The establishment of affable relationships with all the students (including postgraduate students) is an objective that is considered mutually beneficial in HEIs. A healthy relationship between individual students and the institution increases the prospect of meeting students' needs; thus pleasant academic experiences are created. The obvious need for intervention into students' academic journeys

i Timothy Aduojo Obaje,Academic Development Practitioner, taobaje@gmail.com, timothyo@dut.ac.za, Durban University of Technology, ORCid: 0000-0001-8568-6889

ii Rosheena Jeawon, Academic Development Practitioner, jeawond@gmail.com, rosheenaj@dut.ac.za, Durban University of Technology, ORCid: 0000-0003-0704-0593 
as a pathway to enhanced academic experiences, and ultimately to improve throughput rates, presents challenges in determining the best way to address this need (Khauoe, 2020; Botha, 2010; \& Kanakana et al., 2010). One of the many deficits which (subject to one's school of thought) may equally be considered as a strength, is the lack of a common approach that could be adapted by all institutions in the country. Although the unavailability of such a uniform approach is generally perceived as a shortfall, this paper favours the inherent strength of a diversified approach to support students' academic experiences across South African HEIs. Hence, this paper offers a critical review of strengths and challenges that are pertinent to the academic advising strategies of the Durban University of Technology (DUT). Academic advising as a professional and scholarly practice at many South African HEIs is in a developmental phase. In this paper, the authors interrogate and analyse their experiences vis-à-vis the extant literature on academic advising practices. In this way, the paper's recognition of some of the best practices in academic advising contributes to the advancement of improved academic advising practices in South African HEIs.

\section{Historical Background to Academic Advising at the Durban University of Technology}

The White Paper for Post-school Education and Training of the Department of Higher Education and Training (DHET, 2014) asserts the need to develop graduates with the skills and competencies that establish the fundamentals for lifelong learning. These include critical, analytical, problem-solving, and communication skills, as well as the ability to deal with change, diversity, and in particular the tolerance of different views and ideas. This places a high demand and expectation on the South African HEIs to reposition them with the goal of attaining the abovementioned White Paper's objective. It is common knowledge that the vision and objectives of the White Paper for Post-school Education and Training (DHET, 2014), which link with the idea of "free higher education", present HEIs with added challenges. This was uniquely affirmed by Pinheiro (2019, p. iv) in his assertion of the significant levels of pressure which confront the HEIs, where there is a responsibility to support large numbers of students with varying needs, backgrounds, priorities, and expectations. He further notes that "it is within this dynamic context that the South African Council on Higher Education implemented the Quality Enhancement Project (QEP) and the Department of Higher Education and Training (DHET) devised the University Capacity Development Programme (UCDP)" (Pinheiro, 2019, p. iv). It is noteworthy that these university-wide interventions (QEP and UCDP) were designed to systemically enhance higher education in South Africa without surrendering or jeopardising academic excellence in our institutions.

The figure below, which is a product of a report by the DHET and the annual report of the DUT, underscores poor throughput rates across the HEIs in South Africa. 


\section{Figure 1}

\section{DUT Institution and National Total Percentage of Graduates for Three-year Undergraduate} Qualifications in Contact Tuition

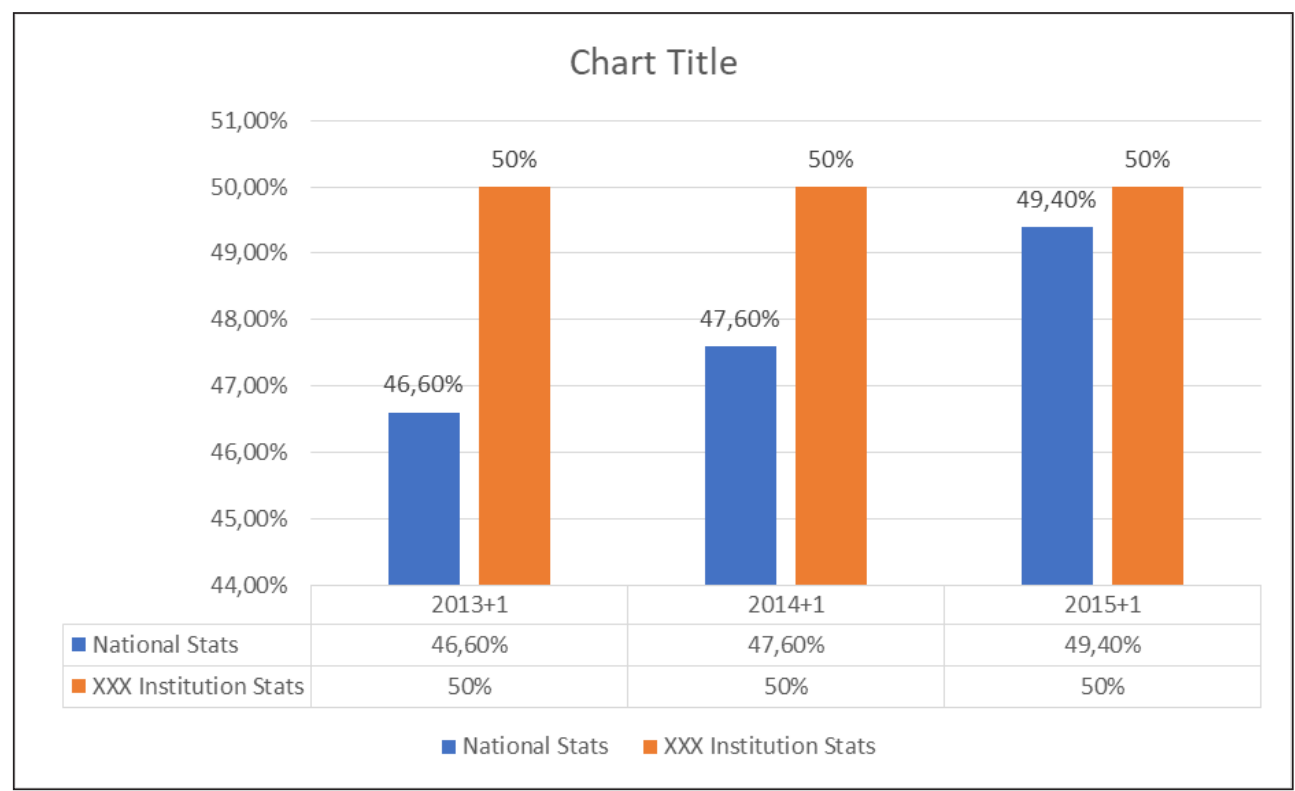

Comparable to the statistics of university students' national throughput rate, the 2018 Annual Report of the DUT displays similar trends in the throughput rate of its students during the same period. Despite the fact that the DUT's graduate throughput rate exceeded the national average, it is worth emphasising that a $50 \%$ throughput rate is still below the desired rate. The graph in Figure 1 makes an indispensable case for the provision of a deliberate and strategically developed programme that is geared towards students' academic development and success. Beyond throughput rates, students' under-preparedness is a cause for national concern; the DUT is no exception. According to Schreiber (2007), the unpreparedness of students is compounded by the fact that some students from rural areas seemingly cannot function effectively in the city-style university environment. The exclusive use of English as the medium of instruction, finding suitable accommodation, and financial challenges compound students' challenges to have productive academic experiences.

In response to the poor throughput rates and in line with global trends, many South African HEIs are now making a conscious and concerted effort to enhance the performance of their existing students through a variety of student interventions. Academic advising is one such student development intervention at the DUT. The Centre for Excellence in Learning and Teaching (CELT) steers the academic advising intervention. CELT is a centre that remains pivotal to the enhancement of quality learning, teaching, and assessment across all academic programmes which are offered at the DUT. 
It is positioned to advance and drive the attainment of the DUT's ENVISION2030 ${ }^{1}$ through its execution and fulfilment of the four interlinked areas in academic development, which include student development, staff development, curriculum development, and institutional development. Within the ambit of student development, the DUT offers a variety of student support services in addition to academic advising. These include but are not limited to the First Year Students' Experience, the Residential Education Programme, and the Technology for Learning. The next section delves into the discourse of academic advising as evident in the extant literature, with a particular interest in the theoretical underpinnings that guide the provision of academic advising at DUT.

\section{Academic Advising Defined}

Generally, academic advising is construed as a process where appointed academic advisors provide ongoing guidance, information sharing, and other relevant support (both academic and non-academic) to students to improve their higher education experiences and to promote their success (Medernach, 2018). There is a widespread understanding that the concept of academic advising was initiated in the United States of America. Considering the benefits associated with it, the trends of academic advising was exported to and implemented in other North American countries. Through such exportation and adaptation, the concepts spread to universities across the world. Its widespread adoption fostered rapid advancement of academic advising, and this is displayed in the chronological history of academic advising in Table 1 below.

\section{Table 1}

Chronological History of Academic Advising

\begin{tabular}{|l|l|}
\hline Era & Description \\
\hline $\begin{array}{l}\text { First Era: } \\
(1620-1870)\end{array}$ & $\begin{array}{l}\text { The first era lasted between } 1620 \text { and } 1870 \text { and was characterised } \\
\text { by a prescriptive approach to academic advising }\end{array}$ \\
\hline $\begin{array}{l}\text { Second Era: } \\
(1870-1970\end{array}$ & $\begin{array}{l}\text { In the second era (1870-1970), student advising as a concept was yet } \\
\text { to be articulated. Nevertheless, HEIs were beginning to provide basic } \\
\text { informal forms of educational support (Shandro et al., 2020,p. 318) }\end{array}$ \\
\hline $\begin{array}{l}\text { Third Era: } \\
(1970-2003)\end{array}$ & $\begin{array}{l}\text { The process associated with student advising had gained predominant } \\
\text { importance within universities; these efforts corresponded to } \\
\text { the needs and efforts to acknowledge, understand, and address } \\
\text { students' needs at universities }\end{array}$ \\
\hline
\end{tabular}

1 ENVISION2030 shows the DNA strands of the DUT and facilitate DUT's community's comprehension of the institution's strategic perspectives. 


\begin{tabular}{|l|l|}
\hline Era & Description \\
\hline $\begin{array}{l}\text { Fourth Era: } \\
(2003 \text { - Undefined) }\end{array}$ & $\begin{array}{l}\text { The fourth era had continued from } 2003 \text { onwards and continues } \\
\text { up to the immediate past. This era was defined by its effort to } \\
\text { establish formal educational councils to monitor students' needs }\end{array}$ \\
\hline $\begin{array}{l}\text { Fifth Era: Characterised by } \\
\text { technological advancement }\end{array}$ & $\begin{array}{l}\text { The fifth historical era may be understood as the current phase } \\
\text { of academic advising; this is the era with an increased invasion } \\
\text { of technology in the academic advising space }\end{array}$ \\
\hline
\end{tabular}

Based on the views of Cardona (2019, p. 1830) and Jones (2019, p. 450), the history of academic advising can be delineated in four phases, and with increasing arguments for a fifth phase. There is no direct correlation between the eras and the approaches to academic advising. This implies that the first era does not solely translate to the first approach to academic advising. Building onto this understanding, the first and second eras in the development of academic advising were dominated by the prescriptive approach to academic advising, given its status as the pioneered approach that generally guided academic advisors. The prescriptive approach is renowned for its use of set protocols that guide actions taken by the advisor, and also for its distinct power dynamic between the advisor and the advisee (Crookston, 2009). Within the frame of this form of advising, the advisor-advisee relationship is strongly guided by the advisor's authority in relation to the student. The students are simply instructed on the line of action that they should take to achieve set goals. Barbuto et al. (2011) encapsulated this approach as the student's adherence to the advisor's input; whereas Drake (2011, p. 10) holds that "prescriptive advising involves limiting advising sessions to academic matters such as course selection, the process of registration, and explanations of degree curricula". Elsewhere, prescriptive advising is understood as a "one-directional" approach. It entails a direct transfer of information from the advisor to the student (recipient), which results in somewhat passive participation of students in the advising processes. It was on this basis that Lowenstein (2009) claimed that the prescriptive model constitutes little more than book-keeping, in the sense that it does not encourage a sense of growth and/or development within the student and/or the advisoradvisee relationship. In summary, the alleged loopholes of the prescriptive approach underscore its superficial and partial nature. Consequently, this approach denies students and the advisor the opportunity to make a positive difference in the life of the student in this unique phase of their journey in life.

The third and fourth eras saw a series of evolution and development in the comprehension, process, and objective of academic advising. These account for the rapid progression of academic advising to include developmental, learning-centred, strength-based, and appreciative approaches. The need for active and engaged student participation in their academic development and learning experiences became evident in the 1970s in a comprehensive set of observations about the value of student-faculty relations. Hardee (1970), cited in Grites (2013, p. 5), advocated for the holistic education of students 
that embodies intellectual, emotional, physical, social, vocational, moral, economic, and aesthetical development. This insight has greatly inspired thinking about the advancement of the developmental approach to academic advising. It advocated a collaborative mind set in advising students; a collaborative disposition encourages a close student-advisor relationship, which is intended to aid students in achieving educational, career, and personal goals through the utilisation of the full range of institutional and community resources (Winston et al., p. 1982). In light of this understanding, writers such as Appleby (2008) view developmental advising as a gradual reallocation of responsibilities for their development from the advisors to the students. In so doing, the students will cultivate the value of accountability, as well as the development of problem-solving and decision-making skills.

The learning-centred approach focuses on the academic competence of the students. Consequently, academic advising within the framework of this approach strives to meet academic-oriented goals rather than developmental goals (Kerr, 2018). A key theoretical difference between learning-centred and developmental approaches is that in learning-centred approaches, the advisor performs a teaching role in the life of the student.

The fundamental tenet of the strengths-based theory is a focus on identifying and working with students' strengths instead of applying deficit remediation when students struggle at university. In strengths-based approaches, students' talents are used as the foundation for advising and everything the processes entailed, including career planning and addressing non-academic concerns that students might express.

Appreciative advisors work with students to identify strengths, sources of motivation, and potential by using a process of positive questioning (Hudson \& Bloom, 2007; Truschel, 2008). This approach assumes that levels of student motivation and persistence peak when institutional expectations align with student perceptions of ability. Hence, the appreciative advisor focuses on attaining this alignment with the student (Truschel, 2008) by means of action-oriented, positive questioning, and the use of positive, supportive language.

The fifth era is characterised by technological advancement. As evident in Tyton Partners' (2015) assertion, technology is becoming increasingly popular as a means of creating and maintaining effective student advising systems at HEIs. This consultancy holds that between 2015 and 2017, the number of South African HEIs that reported on the use of technology to enhance student advising has increased from $32 \%$ to $53 \%$. The advent of technology in academic advising offers enormous benefits given the inherent advantages of technology in education. Technology provides fast and efficient ways for advising systems to contact university students. It is cost-effective and it can be centralised as a feature on the university's student advising webpage for easy access, thereby reassuring students that their queries are taken seriously and that a response is delivered timeously.

Globally, one of the key challenges to academic advising is the lack of trained professionals 
in the field Mikluscak (2010), in his study of training and development provided to community college academic advisors, re-echoed that advisors with the appropriate knowledge and expertise could help students overcome adversities. He noted that without skilful advisors to guide them, students rarely discovered the persistence necessary to successfully navigate the challenges of higher education, and found themselves dropping out within the first year (Mikluscak, 2010). He further asserted that the lack of training and development for advisors contributed to deficiencies in advising services.

The study conducted by Ayuk and Koma (2019) demonstrated that the ratio of permanent academic staff to students in public South African HEIs has progressively improved from 55 students in 2016 to 51 in 2019. In contrast to this, the ratio of academic advisors to registered students at the South Africa HEIs calls for urgent attention. Similar to the DUT, many HEIs in South Africa employ the services of one academic advisor for an entire faculty, college, or department. Practices of this nature undermine the inherent worth of academic advising services, thus making the realisation of the academic advising vision and objectives unattainable.

At the DUT, academic advising is a developmental process that assists students with the clarification of their life/career goals and with the development of educational plans for the realisation of these goals. The advisor serves as a facilitator of communication, as a coordinator of learning experiences through the course and career planning and academic progress review, and as an agent of referral to other university agencies. The following section builds on this understanding of academic advising at the DUT to unpack the institution's adopted academic advising approaches.

\section{Theoretical Underpinnings and Approaches to Academic Advising at the Durban University of Technology}

As acknowledged above, academic advising is informed by a variety of theories subject to the contextual realities of each institution. The various foundational theories include student development, cognitive development, career development, learning, decision-making, multiculturalism, retention, personality, moral development, and adult development (Creamer, 2000). At the DUT, academic advising is informed by the cognitive development theory. In the context of this theory, the institution adopts intrusive and proactive approaches for its academic advising practices. The following section discusses a synopsis of the cognitive-developmental theory and how it informs academic advising practices at the DUT.

\section{Synopsis of the Cognitive Development Theories}

Various theorists have, over time, engaged with cognitive developmental theories. Scholars such as Giligan (1982), Kitchener and King (1981), and Kohlberg (1984) understood cognitive 
development as an ongoing advancement through irreversible, ordered stages of cognitive structure that organises how experiences are perceived and how reasoning functions. Cognitive theories analyse people's thinking processes, rationality, and perceptions of reality around them, with the understanding that "development occurs when [an individual's] cognitive structure is changed, thus enabling new ways of incorporating experience" (Creamer, 2000, p. 23). Such transformation or change occurs when individuals are confronted with the experiences that demand a rethink of prior experiences, long-held beliefs, reconstructed reactions, and answers to events and circumstances.

These theories inform and explain the DUT's institutional practice of academic advising. Academic advising within this institutional context is considered to be an interactive process through which the advisor engages with students to set and achieve their academic goals. According to Creamer (1994, p. 19), "developmental academic advising is the use of interactive teaching, counselling and administrative strategies to assist students to achieve specific learning developmental and life goals." In a similar vein, Tinto (2014) considers academic advising as to the interaction between student engagement and valuable student-staff interactions that allows students to see themselves as valued members of institutional communities. Within the broad spectrum of cognitive-developmental theories, academic advising at the DUT adopts intrusive and proactive approaches in the delivery of their services.

\section{Durban University of Technology's Adopted Approaches to Academic Advising}

This section engages with the approaches to academic advising adopted by the DUT. In addition, it offers a rationale for the implementation of the integrative and proactive (intrusive) approaches to academic advising. Academic advising at the DUT is informed by the embedded strengths and potentials of the integrative and proactive/intrusive approaches. As a result, advising at the DUT adopts a hybrid model that employs best practices from the integrative and the proactive approaches to academic advising.

\section{The Integrative and Proactive (Intrusive) Approaches}

The integrative approach is the product and reflection of the core values of the National Academic Advising Association (NACADA). This approach attempts to delineate the responsibilities of academic advisors in their relationship with students. The approach borrows and combines various aspects from each of the other theoretical models; it largely depends on the needs and/or concerns of each individual student within a given advising session (NACADA, 2017). The reductive advising technique is consistently utilised in the advising context. According to Church (2006) cited in Pinheiro (2019, p. 35), "reductive advising is a strategy that uses deduction to help students decide which courses to choose in assembling a 
coherent curriculum for their degree". This technique is adopted and utilised in the facilitation of students' comprehension and acquisition of decision-making skills.

The intrusive approach is also known as the proactive approach to academic advising; it is more pre-emptive in its dealings with students. Central to the proactive approach to academic advising is its anticipatory disposition. This approach inspires the advisors to deliberately search for potential issues, concerns, and/or stumbling blocks that could negatively interfere with students' academic journey and success. According to Pinheiro (2019 p. 36), "in proactiveintrusive approaches, advising processes are not confined to traditional advising spaces. Instead, the relevant information is obtained from other locations based on campus, including classroom spaces" from lecturers, the department, and the faculty at large to provide timeous and valuable interventions. At the DUT, the intrusive-proactive approach to academic advising emphasises consistent contact with students, lecturers, and students' departments; awareness of students' potential; and actual challenges, early interventions, goals, expectations, needs, and practical tasks.

The adoption of this mixed approach to academic advising helps to position academic advising at the DUT as a safe, effective, and valuable place of support to students in their academic journey. It facilitates the institution's journey with each student in providing a variety of resources and support towards rewarding learning experiences, personal growth, and development.

\section{Best Practices of Academic Advising at the Durban University of Technology: Unpacking its Strengths and Challenges}

Consistent with existing literature, the identified strengths in the best practices of academic advising at the DUT include collaboration and promotion of accountability, whereas the recognised challenges include lack of capacity and required resources.

Academic advising at the DUT, as previously mentioned, is underpinned by the broad cognitive-developmental theoretical perspectives, while employing the strengths of the intrusive and proactive approaches in every sphere of academic advising. Collaboration with colleagues in the student academic development units and with non-academic support units is an indispensable aspect of our strategy. Cross-unit collaboration is a positive element of academic advising at the DUT; this has also been confirmed in other studies related to collaboration in the academic environment (e.g. Bourbous \& Bavaro, 2013). The effort and success in working with the Writing Centre, Student Counselling Office, Student Residence Unit, and even with the Faculty Staff is critical to the successful delivery of academic advising services. The advent of Academic Advising at the DUT was instrumental in building bridges between the various student support units. As academic advisors, the collaborative approach expedited our ability to reach out, thus increasing the level and quality of engagement with students. The collective 
approach to decision-making in certain situations and services delivered to students enriches the value of the services offered. Student observation of such collaboration helps to better encourage the students' reception and valuation of our services. In simple terms, some of the services rendered to our students would not have been possible without the Students' Counselling Office, where counselling was required to realign students to their academic and life goals.

From a managerial perspective, the collaborative element in the academic advising delivery process is drawing attention to issues of accountability and responsibility towards one another as colleagues, and towards the students who are the beneficiaries of the services. As noted by MacTaggert (2017, p. 1), "twentieth-century leadership approaches will no longer suffice the need of contemporary society is acknowledged." The challenges and higher performance expectations from institution management, threats of student unrest, and the severe competition for students and resources necessitate the development of a collaborated and less fragmented approach, to increase the likelihood of delivering on student success. Academic advisors' collaborative skills are instrumental in harnessing the strengths of like-minded units in joint efforts towards the realisation of each stakeholder's objectives. The referral system is of particular significance in academic advisors' delivery of their services. At a secondary level, the referral process and generic collaboration at various levels produce unintended consequences such as keeping watch over one another's services, which ultimately leads to improved quality of services offered to the students.

The sudden outbreak of the global Covid-19 pandemic adds a unique twist to the delivery of accountability in academic advising services. The pandemic has resulted in the shift of services provided in contact mode or within classrooms to digital platforms (Demuyakor, 2020). It has been illustrated that adaptation of learning through digital platforms has been difficult for both students and teachers, and many students have been psychologically demotivated. In response to these challenges, the implementation of academic advising programmes was valuable in promoting the accountability of various stakeholders to the students. This was promoted through the academic advisors' consistent demand of the university community's synchronous and asynchronous service provision to the students. Thus, the DUT was effective within the South African context in advancing best practices in its support and services to the students.

\section{Conclusion}

This article has reviewed the adopted academic advising approaches at the DUT through its enquiry into the experiences of academic advisors in the institutions. The article has offered an opportunity to share and reflect on best practices of academic advising, as evidenced in the collaboration between the advisors, students, and other stakeholders in this institution of higher 
learning. A key aspect of this article is its emphasis on the strategic position of collaboration in the delivery of effective and impactful academic advising services. The article demonstrates the interrelated and interdependent nature of student academic and nonacademic support services. An effective academic advising service inherently relies on the well-being and availability of other stakeholders to collaborate with the goal of rendering much-needed support to the students.

The article has also highlighted a serious challenge of the dearth of trained academic advisors in higher institutions. The ratio of advisors to students still leaves much to be desired. It is strongly recommended that future studies and research delve into this area of interest. It would be a worthwhile effort to decisively unpack and analyse the ratio of academic advisors against students in institutions of higher education to render effective services to the scholarly fraternity.

\section{References}

Appleby, D. C. (2008). Advising as Teaching and Learning. In V. N. Gordon, W. R. Habley, \& T. J. Grites (Eds.), Academic advising: A comprehensive handbook (2nd ed.) pp. 85 -102. Jossey-Bass.

Ayuk, P. T., \& Koma, S. B. (2019). Funding, access and quality conundrum in South African higher education. African Journal of Public Affairs, 11(1), 176-195.

Barbuto,J.E., Story, J. S., Fritz, S. M., \& Schinstock,J. L. (2011). Full range advising:Transforming the advisor-advisee experience. Journal of College Student Development, 52, 656-670. doi:10.1353/csd.2011.0079.

Bloom, J. L., Hutson, B. L., \& He,Y. (2008). The appreciative advising revolution. Stipes.

Botha, P. (2010). Student throughput: The role of the individual lecturer. Progressio, 32(2), 102 116.

Cardona, T.A., (2019). Predicting Student Retention Using Support Vector Machines. Procedia Manufacturing, 39, 1827-1833.

Cate, P., \& Miller, M. A. (2015). A history of academic advising within the academy. In P. Folsom, F. Yoder, \& J. Joslin (Eds.), The new advisor guidebook: Mastering the art of academic advising pp. 39-54. Jossey-Bass.

Church, M. (2006). Integrative Approach to Academic Advising. Academic Advising Today, 29(2).

Cook, S. (2009). Important events in the development of academic advising in the United States. Nacada Journal, 29(2), 18-40.

Creamer, D.G. (2000). Use of theory in academic advising. In Gordon, V.N. and Habley, W.R. Academic Advising: A comprehensive handbook. Jossey-Bass.

Crookston, B. B. (2009). A developmental view of academic advising as teaching. NACADA Journal, 29(1), 78-82. 
Demuyakor, J. (2020). Coronavirus (COVID-19) and online learning in higher institutions of education: A survey of the perceptions of Ghanaian international students in China. Online Journal of Communication and Media Technologies, 10(3), e202018. https://www.ojcmt. net/download/coronavirus-covid-19-and-online-learning-in-higher-institutions-ofeducation-a-survey-of-the-8286.pdf.

Department of Higher Education and Training. (2014). White Paper for Post-school Education and Training: Building an Expanded, Effective and Integrated Post-school System. file:///E: DUT/ CELT/Articles\%20for\%20Publication/Articles\%20for\%20Review/White\%20 Paper \%20on\%20Post-school\%20Education\%20and\%20Training\%20in\%202014.pdf

Drake, J. K. (2011). The role of academic advising in student retention and persistence. About Campus, 16(3), 8-12. DOI:10.1002/abc.20062

Gilligan, C. (1982). In A Different Voice: Psychological Theory and Women's Development. Harvard University Press.

Gillispie, B. (2003). History of academic advising. Retrieved from NACADA Clearinghouse of Academic Advising Resources.

Grites, T. J. (2013). Developmental academic advising: A 40-year context. NACADA Journal, $33(1), 5-15$.

Hardee, M. D., \& Mayhew, L. B. (1970). Faculty Advising in Colleges and Universities. Student Personnel Series. Number Nine. https://eric.ed.gov/?id=ED041326

Jones, K. M. (2019). Advising the whole student: eAdvising analytics and the contextual suppression of advisor values. Education and Information Technologies, 24(1), 437-458.

Kanakana, M. G., Pretorius, J. H., \& Van Wyk, B. (2010, October). Lean six sigma framework to improve throughput rate. In 2010 IEEE 17Th International Conference on Industrial Engineering and Engineering Management (pp. 862-866). IEEE.

Kerr, K. (2018). Promoting and establishing an effective campus-wide academic advising system. University of Nebraska, (294), 1-169.

Khauoe, T. (2020). Factors impacting postgraduate throughput rates at a South African university of technology Doctoral dissertation, Cape Peninsula University of Technology.

Kitchener, K. S. \& King, P.M. (1981). Reflective judgment: concepts in justification and their relationship to age and education. Journal of Applied Developmental Psychology. 2(2), 89-116

Kohlberg, L. (1984). The psychology of moral development: Essays on moral development (Vol. 2). Harper \& Row.

Lowenstein, M. (2009). If advising is teaching, what do advisors teach? NACADA Journal, 29(1), 123-131.

MacTaggert, T. (2017). The 21st century presidency: A call to enterprise leadership. Association of Governing Boards of Universities and Colleges. https://agb.org/trusteeship-article/the-21stcentury-presidency-a-call-to-enterpriseleadership/ 
Medernach, R. (2018, April 8). Intrusive advising and student success. https://richardmedernach. wordpress.com/2018/04/08/intrusive-advising-andstudent-success/.

Mikluscak Jr, G. S. (2010). A qualitative inquiry into the training and development provided to community college academic advisors. University of Phoenix.

Pinheiro, G. (2019). Overview of the History and Evolution of Student Advising. University of the Witwatersrand.

Schreiber, B. M. (2007). Students and their presenting concerns at a Student Counselling Service at a South African university. South African Journal of Higher Education, 21(5), 527-535.

Shandro, J., Kessler, R., Schrepel, C., \& Jauregui, J., (2020). Advising Medical Students during COVID-19: The Case for a Single Emergency Medicine Rotation for All. AEM Education ETraining, 4(3), 318-320.

Tinto, V. (2014). Tinto's South Africa lectures. Journal of Student Affairs in Africa, 2(2), 5-28.

Truschel, J. (2008). Does the Use of Appreciative Advising Work? Learning Assistance Review, 13(2), 7-16.

Tyton Partners. (2015). The evolution of student advising in higher education (Part 1: State of the student advising field.) https://tytonpartners.com/wp-content/uploads/2015/08/Tyton_ PlanningAdvising1.1.pdf

Winston, R. B., Jr., Ender, S. C., \& Miller, T. K. (Eds.). (1982). Developmental approaches to academic advising. Jossey-Bass. 